\section{INDIAN GEOGRAPHICAL NAMES}

THE Committee of the Geographical Society of Bombay appointed to prepare an index of geographical names in India, in vernacular and English spellings, with memoranda--geographical, etymological, antiquarian, and statistical - have published the ontline of a general plan to guide in the formation of the proposed index, and to enumerate the particulars it might properly inciude.

The object is primarily geograplical and etymological, but the Committee hopes information may be placed at its disposal to nake it also historical and statistical.

The committee, therefore, considers that a full index of the kind ought to embrace-

I. Names of towns, villages of any size or note, railway stations, \&c., with the taluka and district or state in which each is situated, its longitude and latitude; the population; name of the river or stream on which each is situated; altitude above the sea-level; the dates and names of founders; the etymology of the name; the Sanskrit or ancient name; notes of connected events, peculiar products or manufactures; places of note, temples, commemorative pillars, \&c., in their vicinity, with references to fuller descriptions already published.

2. Names of the talukas or divisions in each district, witl the area, chief town and population.

3. Shrines and places of pilgrimage, with notes of the objects of adoration or pilgrimage, dates of fairs, \&c., and precise locality.

4. Rivers, their rise, course, and confluence or debouchure ; lakes, with their size or area and products ; hot springs, with their temperature.

5. Mountain ranges, with average heights; peaks, with their greatest altitudes ; hill forts, with notes of events connected with them and their present condition.

6. Valleys, plateaux, \&c., having particular designations, with notes on their peculiarities.

7. Tribes and peculiar sects, with notes of their habitats, castes, race, peculiar deities, occupations, \&c.

These notes are not intended to be lengthy and need seldom extend to half-a-dozen lines; but may generally be restricted to one or two: whilst all detailed information collected might be preserved by the Geographical Society for reference.

If this plan can be well filled up, the proposed list will include the names on the maps of Rennell, Arrowsmith, Allen, Walker and Keith Johnston and in the road-books, with many others in addition. It would thus be of considerable extent and require a large amount of patient labour, besides the collection of much information that has never yet been brought together from the many districts of so vast a country.

The Committee proposes to compile every name in the characters of the vernacular or vernaculars of the district in which it occurs and in the language to which the name belongs. Purely Mulammadian names must be given in Urdu and in the characters of the Hindu dialect of the place; Hindu names in the form or forms used by educated Hindus of the vicinity, whether Hindi, Bengali, Panjabi, Kashmiri, Sindhi, Kachli, Gujarati, Marathi, Uriya, Telugu, Tamil, Malayalim, Singalese, or Burmese; but, for convenience in printing, it may be best to use the Devnagari alphabet for all the Sanskritic dialects at least. Each name should be followed by its transliteration into Roman characters according to the alphabet of Sir William Jones, as now written by the Royal Asiatic and other Societies and by most orientalists, the English spellings in common use and on the Trigonometrical Survey maps, both the English and vernacular forms being arranged so that, either being known, a name may at once be found in its alphabetical place in the index.

The committee hopes to add any peculiar forms of Indian names found in the best-known historical and descriptive works on India, such as the writings of Orme, Dow, Elphinstone, Grant Duff, Mill, Wilson, Thornton, Montgomery Martin, Rennell, Hamilton, \&c.; also the Greek and Sanskrit ancient names so far as they have been iclentified by Lassen, De Saint-Martin, Cunningham, \& $\mathrm{c}$.

Considering the nature and extent of the work, the committee feels that it nust be mainly dependent upon fresh information from each locality. Believing also that with aclecpuate assistance such an index would be of permanent value to all connected with this country, it recommends the Geographical Society to bring the matter before the Government at Bombay, with the request that the committee and society be afforded that assistance in procuring the desiderated information, which Government alone can afford, by obtaining the services of its officers in the Revenue, Educational and other departments, in collecting the vernacular names and other particulars and that the Government of Bombay graciously use its influence in obtaining for the society similar assistance from the other Governments of India.

\section{SOCIETIES AND ACADEMIES}

The Secretary of the Philosophical Socicty of Glasgonv wishes us to state that the report of the proceedings of that Society in our Nismber of the $3 r d$ inst. was not an afficial one. In acceding to this request ave arould point out the destrablentess of the Secretaries of all Societies sending us official reports, since it is only by that means that accuracy can be insured. When this clear duty of an official is performed by an ordinary membir, who, without havsing access to documents and notes, is yet anxious that the work of his Society should be represented, and sends a report faute de mieux, it is impossible always to guard against error. All reports forwardult to us should be as short as possible, distinctly wirtten, and deal only zoith adzances on our previous knowledse.

LONDON

Royal Society, February Io. - The following papers were read : "On some remarkable Spectra of Compounds of Zirconia and the Oxides of Uranium." No. I. By H. C. Sorby, F.R.S. We shall return to this communication. - "On linear differential equations," No. 2. W. H. L. Russell.

"On the mathematical theory of stream-lines, especially those with four foci and upwards." W. J. Macquorn Rankine. A stream-line is the line that is traced by a particle in a current of fluid. In a steady current, each individual stream-line preserves its figure and position unchanged, marking the track of a filament or continuous series of particles that follow each other. The motions in different parts of a steady current may be represented to the eye and to the mind by means of a group of stream-lines. Stream-lines are important in connection with naval architecture; for the curves which the particles of water describe relatively to a ship, in moving past her, are streamlines. If the figure of a ship is such that the particles of water glide smoothly over her skin, that figure is a stream-line sitrfac; being a surface which contains an inclefinite number of streamlines. The author in a previous paper proposed to call such stream-lines Neoüts; that is, ship-shape lines. He refers to previous investigations relating to stream-lines, especially to those of $\mathrm{Mr}$. Stokes, in the Cambridge Transactions for 1842 and I850, on the "Motion of a liquid past a solid," of Dr. Hoppe, on the "Stream-lines generated by a sphere," in the Quarterly Fournal of Mathematics for 1856 , and his own previous papers on "Plane water-lines in two dimensions," in the Philosophical Transactions for I864, and on "Stream-lines," in the Frziosophical Magazine for that year. He states that all the Neo:d or ship-shape stream-lines whose properties have hitherto been investigated in detail, are either unifocal or bifocal; that is to say, they may be conceived to be generated by the combination of an uniform progressive motion, with another motion consisting in a divergence of the particles from a certain point or focus, followed by a convergence either towards the same point or towards a second point. Those which are continuous closed curves, when unifocal, are circular; when bifocal, they are blunt-ended ovais, in which the length may exceed the breadth in any given proportions. To obtain an unifocal or bifocal neoild resembling a iongitudinal line of a ship with sharp ends, it is necessary to take a part only of a streamline : there is then discontinuity of form and of motion at each of the two ends of that line.

The author states that the nccasion of the investigation described in the present paper, was the communication to him by Mr. William Froude of some results of experiments of his on the resistance of model boats, of lengths ranging from three to twelve feet. A summary of those results is printed at the end of a Report to the British Association on the State of "Existing Knowledge of the Qualities of Ships." In each case two models were compared together of equal displacement and equal length the water-line of one was a wave-line with fine sharp ends, that of the other had blunt rounded ends, earh joined to the midship body by a slightly hollow neck; a form suggested, Mr. Froude states, by the appearance of water-birds when swimming. At low velocities, the resistance of the sharp-ended boat was the 